\title{
The Effects of Microcredit on Profitability and the Challenges of Women Owned SMEs: Evidence from Northern Ghana
}

\author{
Eva Atu Alhassan (Corresponding author) \\ Department of Planning, College of Architecture and Planning, \\ Kwame Nkrumah University of Science and Technology, \\ Kumasi, Ghana \\ E-mail: evaatu@yahoo.com \\ Mabel Akosua Hoedoafia \\ Faculty of Economics and Business Administration, \\ Catholic University College of Ghana \\ P. O. Box 363, Sunyani, Ghana \\ E-mail:mhoedoafia@yahoo.com \\ Imoro Braimah \\ Department of Planning, College of Architecture and Planning, \\ Kwame Nkrumah University of Science and Technology, \\ Kumasi, Ghana
}

Received: March 31, 2016 Accepted: May 02, 2016 Published: June 22, 2016

doi:10.5296/jebi.v3i1.9244 URL: http://dx.doi.org/10.5296/jebi.v3i1.9244

\begin{abstract}
Women owned enterprises have limited access to capital as traditional banks shy away from them due to the high risk associated with lending to SMEs. Hence, several Microfinance Institutions (MFIs) sprung up with the aim of providing credit to SMEs especially women entrepreneurs. In this paper, the effect of microcredit from these MFIs on profitability of women owned SMEs is examined with data from 199 women entrepreneurs in the Tamale
\end{abstract}


Metropolis of Ghana. The enterprises were randomly selected from five Microfinance Institutions and categorized based on their economic activities using stratified sampling. Semi structured interview checklist was used to survey the women owned SMEs whilst questionnaires were administered to the Microfinance Institutions. A paired sample t-test was employed to determine the changes in Gross Profit over time after which effect of size was also determined. The results indicate a significant increase in the average monthly gross profit over time.

Keywords: Microcredit, SMEs, Gross profit, Women enterprises, Microfinance Institutions

\section{Introduction}

Microcredit has been identified as an important tool for the poor, including women for the improvement of their socioeconomic status. It provides numerous benefits for beneficiaries such as owners of Small and Medium Enterprises (SMEs) for expanding their businesses. According to Ghadoliya (2000), microcredit plays a crucial role in the socio-economic empowerment of individuals most especially women within households by promoting their participation in decision making at all levels. Similarly, Goetz \&Sen (1994) and Mayoux (2005) posit that, the increase in income of women reduces their vulnerability to domestic violence and also help them have a better control of their reproductive health.

In addition to serving as a source of empowerment at the household level, microcredit has been identified as a key element for the growth of small and medium enterprises (Idowu, 2010). It helps them to build productive capacity, create jobs and contribute to poverty alleviation in developing countries by adopting new technologies (Idowu, 2010). Microcredit has been identified as one of the most important factors in the growth and expansion of SMEs especially women owned enterprises (WOEs). It is believed that credit improves income levels, business expansion, competitiveness, increase sales volume and thereby more profits. It is thought that access to credit enables SMEs to overcome their liquidity constraints and undertake investments (Hiedhues, 1995). In Ghana, credit has been recognized as an essential tool for promoting SMEs growth (Oti-Boateng and Dawoe, 2005).

Notwithstanding the important role microcredit plays in the growth and expansion of SMEs, it has been observed that most formal banking institutions deem it an unattractive venture (World Bank, 1994) in doing business with them because they are considered as high risk clients. Women entrepreneurs especially suffer most as Abor and Quartey (2010) posit that majority of their enterprises are usually home-based and compared to enterprises owned by males, WOEs are operated from home and are mostly not considered in official statistics which affects their chances of gaining access to credit schemes. Women are mostly involved in sole-proprietorship businesses which are mainly micro-enterprises and as such may lack the necessary collateral to qualify for loans. These WOEs are mostly individual or groups engaged in food production from local crops, soap and detergents, fabrics, dressmaking, sale of cement and other building materials, bakeries, wood furniture, hair dressing, electronic assembly and agro processing among others. Despite the vital role of 
women entrepreneurs in the economic development of their families and countries, it has been revealed that they have low business performance compared to their male counterparts (Akanji, 2006). They are faced with low or limited financial and business training, poor savings and inadequate access to credit (Shane, 2003).

In a previous study, we examined the factors that determine the growth of SMEs with a focus on women entrepreneurs (See Alhassan, Hoedoafia \& Alhassan, 2016). Several other studies on women entrepreneurship have identified numerous constraints facing them. In particular, issues relating to employment generation, conditions of service and market expansion, and growth from micro to small and to medium size have been dominant. In this paper, the effect of microcredit on the profitability and the challenges faced by women owned SMEs and MFIs are investigated.

\section{Literature Review}

\subsection{Microcredit as a Development Tool for Poverty Reduction}

Microcredit approach has been increasingly incorporated in the development discourse during the last two decades. Since its inception in Bangladesh, it has spread all over the world and it is now regarded as a useful tool for poverty alleviation. Institutions involved in the delivery of microcredit have helped to reverse the conventional top down approach by creating livelihood opportunities for the poorest citizen, especially women who form about 94 percent of their clients (Thente, 2003).

The former UN Secretary General, Kofi Annan during, the launch of the International Year of Microcredit in 2005, said sustainable access to microfinance helps alleviate poverty by enabling the poor to meet their basic needs and empowering people to make the choices that best serve their needs. Microcredit is one of the broad range of financial tools for the poor, and its role in development has emanated from a number of key factors that include; the fact that the poor need access to resources, with financial services being a major resource, the realization that the poor have the capacity to use loans effectively and re-pay loans.

Microcredit is now considered an effective development tool of poor people especially women. This supports the assertion of Guerin (2006) that, it has a positive and significant effect on poverty reduction and women empowerment. Several authors such as Khandker (1998) and Derbile (2003) enumerated some successes of microcredit in alleviating families' poverty. They noted that it has helped beneficiaries mostly women to venture into gainful employment. It has improved their income level and contributed to the provision of household and other essential basic needs. This has led to the improvement of the household livelihood and improved women contribution to household decision making (Aasoglenang, 2000).

Another factor is that microcredit programmes provide women in Africa with access to networks and markets which equip them with a wider experience of the world. Their access to information and possibilities of other social and political roles are also enhanced (Mayoux, 1997). Proponents of microfinance argue that small credits to poor people could serve as a powerful tool for reducing poverty (Khan and Rahaman, 2007). This is in agreement with the 
UNCDF's (2009) study that, microcredit for farmers or small businesses serves as an effective tool for expanding economic opportunities and reducing the vulnerabilities of the poor. Likewise, Pronyk et al. (2007) argue that microcredit presents low income earners with their basic needs. Accessing finance has been identified as a key element for SMEs to succeed in their own drive to expand and grow, create jobs and contribute to poverty reduction in developing countries (Idowu, 2010). The effect of microcredit on the growth of enterprises has received a lot of attention worldwide. Several researchers have suggested that a well-developed microcredit system can help SMEs access affordable credit services, thereby reducing poverty most especially among women entrepreneurs. The provision of microcredit to SMEs can also improve the economic conditions in developing countries by fostering innovation, macro-economic resilience and GDP growth (Dahlberg Report, 2011). The determining factor for a firm's growth is the availability of resources such as credit to the firm.

Gender activists also argue in favour of microfinance as a means of empowerment by supporting women's economic participation. Boyle (2009) opines that by supporting women's economic involvement, microfinance aids to improve household well-being. Littlefield (2005) reports that the opportunities created by credit availability helps a lot of poor people to invest in their businesses, educate their children, improve their healthcare and promote their overall well-being. Karlan and Zinman (2006) also observed that recipients of microcredit were better off than non-beneficiaries. This observation was also made by Khan and Rahaman (2007), who identified that recipients improved their livelihoods and moved out of poverty.

Both the World Bank (2002) as well as the Beijing Platform for Action of 1995 (BPFA, Women and Poverty) have recognized women's access to financial resources as important strategies for poverty reduction and donors have increasingly directed microfinance services to women. The International Labour Organization (2006) stressed that microfinance services lead to women's empowerment by positively influencing women's decision-making power and enhancing their overall socio-economic status. Microfinance services had reached over 79 million of the poorest women in the world by the end of 2006. Microfinance thus has the potential to make a significant contribution to gender equality and promote sustainable livelihoods and better working conditions for women. Similarly, Barnes (2005) and Robinson (2004) confirmed the positive impact of microcredit on borrowers' income, food security, nutrition, as well as education of children.

Microcredit enables the low income earners especially women who do not have access to formal banking to increase their income, build assets and diversify livelihood options. Hence, reducing their vulnerability to economic stress. It has been established in the past that the provision of financial products and services to poor people by MFIs can be practicable and sustainable as MFIs can cover their full costs through adequate interest spread and by operating efficiently and effectively. Contrary to the contribution of Microcredit to the economic empowerment of the poor, it is not a magic solution that will propel all of its clients out of poverty. It should be seen as only one of the tools to reduce poverty. Roodman (2009) asserts that microcredit actually leave beneficiaries poorer, just as credit cards and mortgages 
have made people poorer in developed countries because according to Ditcher (2006), the promise of microcredit is irresistible but the hope for poverty reduction and impact of microcredit remains elusive. Karnani (2007) shared a similar view on microfinance programmes and argued that though microcredit yields some non-economic benefits, it does not significantly reduce poverty and that the promise of microfinance is less attractive than the reality. He argued that the best way to alleviate poverty is to create jobs and increase worker productivity but not through microcredit.

To support the above assertion, Sachs (2009) stated that microfinance may not be appropriate in poverty alleviation. He noted that poor borrowers hardly invest the micro credit in fixed assets or new technology; rather, they use that to sustain themselves and their families. In view of this, Aguilar (2006) and Ausburg (2008) recommend the need for a plus component which involves training in financial management, marketing and managerial skills and market development skills for beneficiaries of micro credit in order to succeed.

\subsection{Theoretical Link between Microcredit and SME Growth}

Accessing adequate amount of credit is considered to be an important factor in increasing the development and growth of SMEs. It is known to boost income levels, increase employment and thereby reduce poverty. It is alleged that access to credit enables low income earners to overcome their liquidity constraints and undertake some investments such as the improvement of farm technology inputs thereby leading to an increase in agricultural production (Hiedhues, 1995). Navajas et al. (2000) assert that the main objective of microcredit is to improve the wellbeing of the poor as a result of better access to microcredits that are not offered by the formal financial institutions.

A study carried out in Machakos Municipality of Machakos District in Kenya in 2012, revealed that MFIs play a major role in credit provision to the SMEs, and this credit has contributed to the growth of businesses in terms of number of employees, asset base, level of stocks and services of the businesses. It also indicated that the credit services in businesses which do not show increased profitability, changes in stock levels and services are used to sustain the business and avoid possible collapse (Munyao, 2012).

Muktar (2009), however, argues that finance is a precondition for the growth of enterprises and therefore it is very essential in a business growth through improved capitalization of business, long-term income growth and employment creation (Kevan and Wydick,2001). Access to credit further increases SME's risk-bearing abilities; improve risk-copying strategies and enables consumption smoothing overtime.

Buckley (1997) argues that, the indicators of success of microcredit programmes namely high repayment rate, outreach and financial sustainability do not take into consideration what impact it has on micro enterprise operations. A research carried out in three countries including Kenya, Malawi and Ghana, in relation to the effect of micro credit on SME growth concluded that there was no significant and sustained impact of micro credit on clients in terms of SME development, level of employment and incomes but rather tends to stabilize income and preserve rather than create jobs (Burger 1989). 
Dunn and Arbuckle (2001), however, disagreed with Burger (1989) by concluding that microcredit has a positive impact on microenterprise revenue, enterprise employment, and household income. Zeller and Sharma (1998) support the assertion that micro credit can aid in the improvement or establishment of household wellbeing, possibly making the difference between alleviating poverty and economically secure life.

Facts by Coleman (1999) suggest that the village bank credit did not have any significant impact on physical asset accumulation. The women used the money from the village banks for consumption purposes and were forced to borrow from money lenders at high interest rate to repay the village bank micro credits so as to qualify for more microcredits and ended up in a vicious cycle of debt. The main observation from this study was that credit was not an effective tool to help the poor out of poverty or enhance their economic condition. It also concluded that the poor are too poor not because of lack of access to credit but some other hindering factors such as lack of unequal land distribution and access to markets. This view was also shared by Adams and Von Pischke (1992).

A study of thirteen MFIs in seven countries carried out by Mosley and Hulme (1998) concluded that household income tends to increase at a decreasing rate as the income and asset position of the debtors improve. Diagne and Zeller (2001) in their study in Malawi suggest that microfinance do not have any significant effect in household income meaning no effect on SME development. Kotir and Obeg-Odoom (2009) in a study of 139 households in one rural area of the Upper West Region of Ghana, found that: (a) Beneficiaries of micro-credit divert a significant portion of such microcredits into household consumption-albeit with moderate impact on household productivity and welfare; and (b) Micro-credit has modest impact on rural community development.

Some studies have also argued that using gender empowerment as an impact indicator, microcredit has a negative impact (Goetz and Gupta, 1994; Montgomery, 1996). Using a "managerial control" index as an indicator of women empowerment, it came to a conclusion that the majority of women did not have control over micro credits taken by them when married. The women were however the main target of the credit programme. The management of the micro credits was made by the men hence not making the development objective of lending to the women to be met (Goetz and Gupta, 1994). Evidence from an accounting knowledge as an indicator of women empowerment concluded that women are marginalized when it comes to access to credit (Ackerly, 1995).

A study conducted by Fiasorgbor (2014) in the Walewale district of the Northern Region of Ghana found that microcredit has had great effect on enterprises in the Walewale area. Beneficiaries were able to purchase raw materials and also their capital was improved. Thus it helped to increase the welfare of the people by helping them meet their basic needs thereby reducing poverty levels in the community. Again, Acheampong (2002) also asserts that micro credit schemes had helped SMEs to expand their areas of operation and had significantly enhanced the working capital of the beneficiaries. It has also been revealed by Quaye (2011) that access to credit had positive effects on the businesses of beneficiaries. The credits granted helped them to boost their capital and expand their businesses. Contrary to these 
views, Atandi and Wabwoba (2013) identified that credit to SMEs did not necessarily lead to increase in assets base and also did not guarantee a bigger market share. The effect of credit on SMEs performance with respect to stock levels showed that less money was allocated to the purchasing of additional stock. It was also found that employment levels did not improve.

Profitability is one of the important measures of growth that must be considered as it is unlikely that enterprise growth can be sustained without profits being available for reinvestment in the enterprise. Growth can be considered in terms of net profit margins. According to Stewart and Hodgkinson (1991), if the definition of enterprise is considered as the creation of rents through innovation, where rents are defined as above average earnings relative to competitors, then profitability measures are mostly attractive. This also implies that economic success is required by high performance firms.

\section{Methodology}

\subsection{Study Area}

The study was conducted in the Tamale Metropolitan area of the Northern Region of Ghana. The Tamale metropolis shares boundaries in the north with the Sagnarigu District; Mion District in the East; Tolon District in the West; Central Gonja district in the South West and East Gonja district in the South. The Metropolis had in 2010 a total population of 371,351 with males constituting 185,995 and females 185,356 (GSS, 2012). About 75.7\% of women entrepreneurs in this area are aged between 30 and 49 and characterized by low level of education (Alhassan, Hoedoafia \& Alhassan, 2016). According to MoFEP (2012), there has been an increase in growth in the local economy with the expansion of SMEs development that has led to a reduction in the high unemployment rates. About $42 \%$ of the working class are engaged in agriculture and related activities. Majority of the workforce representing 58\% are engaged in Sales, Services, Transport and Production. This is as a result of the increase in Marketing, Banking and other Non -Governmental activities in the Metropolis.

\subsection{Data Collection}

The target population of the study was women entrepreneurs who have accessed credit from selected MFIs in the Tamale Metropolis. The MFIs were selected using simple random sampling while stratified sampling was used to categorize the women entrepreneurs according to the economic activities they are engaged in (see table 1 below). This includes petty trading, agro processing, and hair dressing among others. Semi structured questionnaires were employed for the qualitative part of the work while semi structured interviews were used to gather quantitative data. The data was analyzed using the Statistical Package for the Social Sciences (SPSS) Version 20 and Microsoft Excel tools. 


\section{Macrothink}

Table 1. Economic activities undertaken by respondents

\begin{tabular}{|l|l|l|}
\hline Economic activities & Number & Percentage (\%) \\
\hline Petty Trading & 172 & 86.5 \\
\hline Agro processing & 8 & 4 \\
\hline Bakery & 6 & 3 \\
\hline Dress making & 8 & 4 \\
\hline Hair dressing & 5 & 2.5 \\
\hline Total & $\mathbf{1 9 9}$ & $\mathbf{1 0 0}$ \\
\hline
\end{tabular}

Source: Authors construct with data from the Microfinance Institutions.

\subsection{Paired Sample t-test}

A paired sample t-test was used to determine if there were changes in Gross Profit over time after which the effect of size was also determined. The effect of size was determined to find out whether the difference in the means is large enough to be practically meaningful. An effect size $d=0.3$ implies small effect while $d=0.5$ and $d=0.8$ imply medium size and large size respectively. The paired sample t-test was computed from:

$$
t=\frac{d^{-}}{\sqrt{s^{2} / n}}
$$

Where $\mathrm{d}^{-}$is the mean difference, $\mathrm{s}^{2}$ is the sample variance, $\mathrm{n}$ the sample size and $\mathrm{t}$ is the paired samples t-test. The time period considered was the period between when the first MFI loan was obtained and the time the study was conducted. Since the study measures the effect of micro credit on profitability over time for the same participants, a paired-samples t-test was identified as appropriate. The hypotheses for the paired-samples t-test are:

$\mathrm{H}_{0}$ (null hypothesis): there is no significant difference between the means of the pre and post loan periods.

$\mathrm{H}_{1}$ (alternative hypothesis): there is significant difference between the means of the pre and post loan periods. 


\section{Macrothink}

\section{Results and Discussions}

\subsection{Effects of Microcredit in the Post Loan Period}

The effects of microcredit in the post loan period are shown in table 2 below. The enterprises that benefited from the MFIs registered increases in mean, median and modal gross profit levels as seen in the table. In general, businesses had registered growth in their gross profit levels in the post-loan period, though the change was marginal. This corroborates the conclusions of (Dunn and Arbuckle, 2001) that access to microcredit resulted in an increase in beneficiary enterprise revenues and profits. The results are also in line with the findings of Loca and Kola (2013) who found that access to microcredit increased the average daily, monthly and annual revenues of beneficiary SMEs in Albania. The use of the median as a measure of growth between the pre-and-post loan periods in the current paper was however the preferred indicator since it eliminated the problems associated with outlier effects on the position of the mean.

Table 2. Effects of microcredit in the post loan period

\begin{tabular}{|l|l|l|}
\hline \multirow{2}{*}{} & \multicolumn{2}{|l|}{ Estimated Monthly Gross Profit (GHS) } \\
\hline \multirow{2}{*}{ No } & Before After \\
\hline Unstated & 159 & 156 \\
\cline { 2 - 4 } Mean & 41 & 44 \\
\hline Median & 203.34 & 273.09 \\
\hline Mode & 120.00 & 200.00 \\
\hline Std. Deviation & 200.00 & 300.00 \\
\hline Minimum & 242.31 & 271.20 \\
\hline Maximum & 2.00 & 5.00 \\
\hline
\end{tabular}

Source: Authors estimations 


\section{Macrothink}

\subsection{The Effects of Microcredit on Gross Profit Growth Rate}

Figure 1 below shows the effects of microcredit on the Gross Profit Growth Rate. From the figure, 74 percent of the enterprises registered an increase in their gross profit over the period of trading with the loans, 15.2 percent of the enterprises also registered no change in growth in their gross profit and 10.3 percent of the enterprises recorded a decline in gross profit. This implies that access to microcredit resulted in: a) an increase in gross profit of most SMEs which is in line with the findings of (Loca and Kola, 2013; Dunn and Arbuckle, 2001), thereby supporting the general assertion that microcredit leads to SMEs growth (Fiasorgbor, 2014; Quaye, 2011; Acheampong, 2002) b) other SMEs only managed to sustain themselves and not run out of business corroborating the results of (Munyao, 2012; Burger, 1989) c) whilst some SMEs recorded losses, thus confirming the conclusions that microcredit does not result in enterprise growth but rather has the potential in placing its clients in a vicious cycle of poverty (Atandi and Wabwoba, 2013; Abiola, 2012; Kotir and Obeg-Odoom, 2009; Diagne and Zeller, 2001; Coleman, 1999; Adams and Von Pischke, 1992 ). The Study data showed significant differences in terms of the enterprises gross profit status. While some enterprises recorded growth in profits during the post loan period, other enterprises either had a decline or stagnation in gross profits. Even though a greater percentage of the enterprises recorded increases in gross profit, the change in profits was marginal.

Figure 1. The Effects of Microcredit on Gross Profit Growth Rate

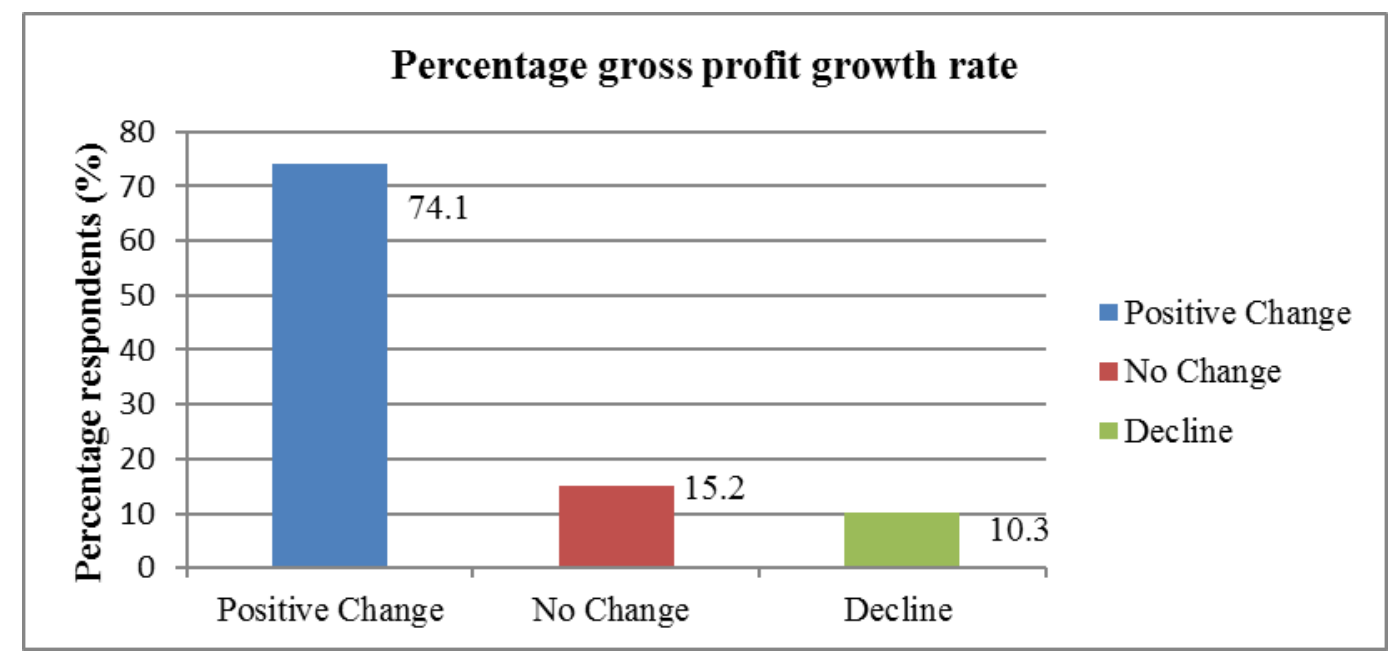

Source: Authors' construct 


\section{Macrothink}

\subsection{Results of a Paired Samples t-test on Growth Indicator}

A paired-samples t-test was used to determine significant changes (mean difference) in gross profit of the SMEs studied between the time when the women entrepreneurs obtained their first MFI loan and the period when this study was conducted. Table 3 shows the paired sample statistics for the gross profit paired t-test presented in table 4.

Table 3. Paired Samples Statistics

\begin{tabular}{|c|c|c|c|c|c|c|}
\hline \multicolumn{7}{|c|}{ Paired Samples Statistics } \\
\hline & & Mean & $\mathbf{N}$ & Std. Deviation & $\begin{array}{l}\text { Std. } \\
\text { Mean }\end{array}$ & Error \\
\hline \multirow{2}{*}{ Gross profit } & $\begin{array}{l}\text { Average monthly gross profit at } \\
\text { the time of the study }\end{array}$ & 265.46 & 145 & 254.561 & 21.140 & \\
\hline & $\begin{array}{l}\text { Average monthly gross profit at } \\
\text { the time of applying for the first } \\
\text { MFI loan }\end{array}$ & 206.21 & 145 & 251.144 & 20.856 & \\
\hline
\end{tabular}

Source: Authors' estimations

From table 3 above, it can be observed that, the average monthly gross profit during the study (265.46 \pm 254.561 GHS) was higher as compared to when the loan was first received (206.21 \pm 251.144 GHS), a significant increase of 59.25 (95\% CI, 28.390 to 90.107) GHS, t (144) = $3.795, \mathrm{p}<.0001, \mathrm{~d}=0.315$ was recorded (see table 4 below). This implies that there is evidence to suggest that participants experienced statistically significant growth in gross profits when exposed to microcredit than the pre loan period.

Although the results indicate a significant increase in the average monthly gross profit between the period when the first MFI loan was taken and the period when the study was conducted, a further investigation of the practical importance of the significance of the results shows a small effect $(\mathrm{d}=0.315)$. This indicates that the change in the monthly gross profits between the two time periods is of less practical importance to the operation and growth of the enterprises. 
Table 4. Paired Samples $\mathrm{t}$ - test

\begin{tabular}{|c|c|c|c|c|c|c|c|c|c|}
\hline \multicolumn{10}{|c|}{ Paired Samples Test } \\
\hline & & \multicolumn{5}{|c|}{ Paired Differences } & \multirow{3}{*}{ e } & \multirow[t]{3}{*}{ df } & \multirow{3}{*}{$\begin{array}{l}\text { Sig. } \\
\text { (2-tailed) }\end{array}$} \\
\hline & & \multirow[t]{2}{*}{ Mean } & \multirow[t]{2}{*}{$\begin{array}{l}\text { Std. } \\
\text { Deviation }\end{array}$} & \multirow[t]{2}{*}{$\begin{array}{l}\text { Std. } \\
\text { Error } \\
\text { Mean }\end{array}$} & \multicolumn{2}{|c|}{$\begin{array}{l}95 \% \text { Confidence } \\
\text { Interval of the } \\
\text { Difference }\end{array}$} & & & \\
\hline & & & & & Lower & Upper & & & \\
\hline $\begin{array}{l}\text { Gross } \\
\text { profit }\end{array}$ & $\begin{array}{l}\text { current gross } \\
\text { profit } \\
\text { monthly gross } \\
\text { profit at the time } \\
\text { of applying for } \\
\text { the first MFI } \\
\text { loan }\end{array}$ & 59.248 & 187.995 & 15.612 & 28.390 & 90.107 & 3.795 & 144 & .000 \\
\hline
\end{tabular}

Source: Authors' estimations

\subsection{Challenges of SMEs}

The challenges of SMEs have been discussed at both the lender and borrower levels. At the lender level, the following challenges were revealed from the survey.

\subsubsection{Lender Level Challenges}

a) Poor record keeping: A significant number of women entrepreneurs lack the basic literacy needed for proper book keeping. Hence, they shy away from formal banking and other formal business processes. It is challenging for entrepreneurs who have no formal education to keep records hence establishing the credit worthiness of their businesses is difficult. From data collected on the level of education of women entrepreneurs in the Tamale Metropolis by Alhassan, Hoedoafia and Alhassan(2016), 69.3\% had no formal education and $20.1 \%$ of them had primary education and only $1 \%$ of the respondents had tertiary education.

b) Lack of confidence in MFIs: According to the MFIs, some of the women lack confidence in them due to the experiences they had encountered with some other MFIs and other financial intermediaries such as fraud. As a result of this, the entrepreneurs feel reluctant to save large amounts of money with the MFIs which is one of the sources of funds for MFIs. This was evident in the data gathered as $95.9 \%$ of the respondents keep their operating capital mostly cash in hand.

c) Inadequate funds: The demand for loans according to one microfinance manager is 
overwhelming and MFIs do not have enough funds to cater for all clients.

d) Weekly repayment not favourable: The weekly loan repayment is unfavourable to entrepreneurs since they are unable to generate enough income for such repayment schedules.

f) Unfavourable interest rates: SMEs get stagnant at a point during the loan cycle due to the high interest rates. For group loans members of a group are compelled to pay for a member who defaults. The MFIs however confirmed that such interest rates are being charged so as to keep the institutions in operation and avoid possible collapse.

\subsubsection{Borrower Level Challenges}

The women entrepreneurs were asked to identify the challenges they faced in their businesses with regard to borrowing. The challenges identified are summarized in table 5 below and explained.

Table 5. Challenges faced by Women Entrepreneurs

\begin{tabular}{llll}
\hline Challenges & Yes & No & N \\
\hline Inadequate capital & $85.2 \%(109)$ & $14.8 \%(19)$ & 128 \\
Lack of accounting skills & $3.2 \%(4)$ & $96.8 \%(121)$ & 125 \\
Short repayment period & $91.4 \%(117)$ & $8.6 \%(11)$ & 128 \\
Shrinking markets/increased competition & $24.0 \%(30)$ & $75.2 \%(94)$ & 125 \\
High interest rate & $83.3 \%(105)$ & $16.7 \%(21)$ & 126 \\
\hline
\end{tabular}

Source: Authors' estimations

a) Inadequate loan amounts: the women complained about low amounts of capital. This is confirmed by the data in Table 5 that showed that over 85 percent of the women entrepreneurs lacked adequate capital. This is also evident from Alhassan, Hoedoafia and Alhassan (2016) from the data collected on the amount of loan received by the entrepreneurs. About $40.2 \%$ of the entrepreneurs received amounts of $200-400$ Ghana cedis and $49.2 \%$ of the women entrepreneurs received amounts ranging from $401-600$ Ghana cedis. Only $9.5 \%$ of them received 800 Ghana cedis and above.

b) Short repayment period: The first most cited challenge by the women entrepreneurs was short repayment period as stated by $91.4 \%$ of the respondents. This finding was confirmed by the MFIs whose maximum repayment periods are four months and six months for group loans and individual loans respectively. This has resulted in the inability or difficulty in completing the loan cycle by some of the women as scheduled. Hence denying the women a 
second loan upon completion of the first loan cycle due to default.

c) High interest rate: high interest rate was the second most cited challenge the women faced. SMEs who borrowed loans from the MFIs had to repay loans at interest rates as high as $6 \%$, $5 \%, 4 \%$ and $3.5 \%$ per month or $72 \%, 60 \%, 48 \%$ and $42 \%$ per year. This was confirmed from the data gathered from the MFIs. It has however been observed that though a greater percentage of the SMEs recorded positive growth in profits, the change was marginal. So the low incomes and high interest rates have led to high default rate among the SMEs.

\subsubsection{Assistance Received in Militating Against Challenges}

The types of assistance received in militating against the above challenges are presented in table 6 below. The assistance listed in the table were mentioned by the respondents as services offered them by the MFIs they were operating with. Training services was the most mentioned assistance received by the respondents and this was also confirmed by the MFIs. Despite the training services being offered them, majority of the entrepreneurs still have challenges with good record keeping. This may be attributed to the fact that a greater proportion of the respondents had no formal education.

Table 6. Type of assistance received in militating against challenges

\begin{tabular}{lll}
\hline Assistance & Frequency & Percent \\
\hline Training services & 113 & 98.3 \\
Access to credit & 1 & 0.9 \\
Provision of market information & 1 & 0.9 \\
Total & 115 & 100 \\
\hline
\end{tabular}

Source: Authors Construct

\subsection{Challenges Faced by the MFIs}

The MFIs as financial intermediaries also face certain challenges. Defaulting on loan repayment was one of the problems mentioned by the MFIs most especially with the individual lending system. In the case of group lending, default by any member put a strain on the other members, and this had implications for the group dynamics and survival of that group. For the individual entrepreneur who defaulted, there was a penalty for each month the loan remained unpaid, which meant an increased financial burden on them. Additionally, some defaulters ended up hiding from the loan providers and this had implications on their businesses as they were not available to attend to them. These defaulters are usually denied the opportunity of being given subsequent loans because of their inability to fulfil the contractual agreements. Other challenges faced by the MFIs included entrepreneurs operating and benefiting from two or more institutions, lack of confidence by entrepreneurs, Inability to 
meet Bank of Ghana regulatory requirements, lack of business registration documents and high demand for credit.

\section{Conclusion}

The effects of microcredit on performance of women owned SMEs in the Tamale Metropolis in terms of profitability has been investigated. Furthermore, the challenges faced by these women owned SMEs and some MFIs in the Tamale Metropolis have been studied. Results from the study indicate that there was a significant increase in the average monthly gross profit over time. A further investigation however shows a small effect size $(d=0.315)$ indicating that the change in the monthly gross profits observed is of less practical importance to the operation of the enterprises. In order to sustain microcredit impact on clients, it was observed from the study that, there is the need for credit institutions to review their interest rates, loan repayment schedules and the loan amounts offered SMEs so as to enhance the performance and financial sustainability of these enterprises.

\section{References}

Aasoglenang, T. 2000. The District Assembly Common Fund: A case study of Nandom in the Lawra District. Tamale: Unpublished undergraduate project work, University for Development Studies. Department of Integrated Development Studies

Abiola, B. 2012. "Effects of Microfinance on Micro and Small Enterprises (Mses) Growth in Nigeria" Asian Economic and Financial Review. Vol.2, No. 4, 1 - 16

Abor, J. \& Quartey, P. 2010. Issues in SME Development in Ghana and South Africa. International Research Journal of Finance and Economics, 39, 218-228

Acheampong, K. 2002. Microcredit for African women. [Online] Available: http://www.mordernghana.com (September 12, 2014)

Ackerly, B.A. 1995. Testing the tools of development: credit programmes, loan involvement and women's empowerment, in "Getting Institutions Right for Women in Development". IDS Bulletin, 26 (3), 35-46

Adams, D. W. and Von Pischke, J.D. 1992. Microenterprise Credit Programs: Déjà Vu". World Development, 20 (10): 1463-1470

Aguilar, V.G. 2006. Is Micro-Finance Reaching the Poor? An Overview of Poverty Targeting Methods. [Online] Available: www.globalnet.org (August 16, 2014)

Akanji, O. 2006. Microfinance as a strategy for poverty reduction. Central Bank of Nigeria, Economic and Financial Review, 39(4)

Alhassan, A. E., Hoedoafia, A. M. and Alhassan, A. E. 2016. Entrepreneurial Characteristics and Business Profile of Women Owned Small and Medium Enterprises: A Case Study of the Tamale Metropolitan Area. Forthcoming in: Business and Management Strategy. 
Alhassan, A. E., Hoedoafia, A. M. and Alhassan, A. E. 2016. Determinants of SMEs Growth in the Tamale Metropolis using Logistic Regression. Business and Economic Research, 6(1), $324-336$

Atandi, F.G \& Wabwoba T.B. 2013. Effect of Credit on Micro and small Enterprises Performance in KitaleTown. International Journal of Academic Research in Business and Social Sciences, 3(9), 570-583

Atandi,F.G and Wabwoba, T.B. 2013. Effect of Credit on Micro and small Enterprises Performance in Kitale Town. International Journal of Academic Research in Business and Social Sciences, 3(9), 570-583

Augsburg, B. 2008. Microfinance Plus - Impact of the 'Plus' on customers' income in Rural Areas.University of Maastricht, the Netherlands. [Online] Available: http://conservationfinance.wordpress.com (September 10, 2014)

Barnes, C. 2005. Micro-credit and Households Coping with HIV/AIDS: A Case Study from Zimbabwe. Journal of Microfinance. 7(1), 55-77

Boyle, G. 2009. Be the Change: Empowering Women through Microfinance. [Online] Available: http://www.brazencareerist.com (October 25, 2014)

Buckley, G. 1997. Microfinance in Africa: Is it either the Problem or the Solution? World Development report, 25(7), 1081-1091

Burger, M. 1989. Giving Women Credit: The Strengths and Limitations of Credit as a tool for Alleviating Poverty. World Development, 17(7), 1017-1032

Burger, M. 1989. Giving Women Credit: The Strengths and Limitations of Credit as a tool for Alleviating Poverty. World Development. 17(7), 1017-1032

Coleman, B.C. 1999. The Impact of Group Lending in North East Thailand. Journal of Development Economics, 60, 105-141

Coleman, B.C. 1999. The Impact of Group Lending in North East Thailand. Journal of Development Economics, 60, 105-141

Dalberg Report, 2011. Report on support to SMEs in Developing Countries through Financial intermediaries.

[Online] Available: http://eudevdays.eu/sites/default/files/dalberg_sme-briefing-paper.pdf $\quad$ on $\quad$ 09/09.2014. (October 20, 2014)

Derbile,E. K. 2003. Women in non-farm enterprise development and poverty reduction in Kasena-Nankane District of Northern Ghana. Unpublished master's thesis Kwame Nkrumah University of Science and Technology, Department of planning

Diagne, A and Zeller, M. 2001. Access to Credit and its impacts in Malawi. Research Report No.116 Washington DC, USA: International Food Policy (IFPRI)

Dichter, T. W. 2006. Hype and Hope: The Worrisome State of the Microcredit. Drawnfrom 
Bangladesh, the Philippines, Tunisia and Zimbabwe. Geneva: ILO

Dunn, E. and Arbuckle, J. G. Jr. 2001. The impacts of microcredit: A case study from Peru. [Online] Available: http://pdf.usaid.gov/pdf_docs/Pnacn574.pdf (October 25, 2014)

Fiasorgbor, A. D. 2014. Microfinance and the wellbeing of rural entrepreneurs. International center for business research paper 3, 1-8

Ghadoliya, M.K. 2000. Empowering Women through Self-Help Groups. New York: World Bank

Goetz, A.M \& Sen Gupta, R. 1994. Who Takes the Credit: Gender Power and Control over use in Rural Credit Programs in Bangladesh. World Development, 24(1), 45-63.

GSS 2012. 2010 Population and Housing Census. Summary report of final results. http://www.statsghana.gov.gh/docfiles/2010phc/Census2010_Summary_report_of_final_resul ts.pdf

Guerin, I. 2006. Women and Money Lessons from Senegal. Development and Change, 37(3), $549-570$

Heidhues, F. 1995. Rural Finance Markets-An Important Tool to Fight Poverty. Quarterly Journal of International Agriculture, 34 (2), 105-108

Idowu, F.C 2010. Impact of Microfinance on Small and Medium-Sized Enterprises in Nigeria.International conference on Innovation and management. [Online] Available: www.povertyactionlab.org (September 14, 2014)

International Labour Organisation 2006. Small change, Big changes: Women and Microfinance. [Online] Available: http://www.ilo.org/wcmsp5/groups/public/---dgreports/ ender/documents/meetingdocument/wcms_091581.pdf on 09/09/2014 (September 9, 2014)

Karlan, D. and Zinman, J. 2006. Credit Elasticities in Less Developed Economies: Implications for microfinance. American Economic Review, 98 (3), 1040-1068

Karnani, A. 2007. Microfinance Misses its Mark, Stanford Social Innovation Review. [Online] Available:http://www.nyu.edu/reynolds/pdf/Microfinance\%20Misses\%20its\%20Mark_SSIR \%20article.pdf (September 14, 2014)

Khan, M.A. and Rahaman, M.A., 2007. Impacts of Microfinance on Living Standards, Empowerment, and Poverty Alleviation and Poor People: A Case Study on Microfinance in the Chittagong District of Bangladesh. [Online] Available: http://www.essays.se (September, $15,2014)$

Khandker, S. R. 1998. Fighting poverty with Micro credit: experience in Bangladesh. NewYork: Oxford University Press. [Online] Available: http://documents.worldbank.org/curated/en/1998/10/438887/fighting-poverty-microcredit-ex perience-bangladesh (September 20, 2014)

Kotir, H. and Obeg - Odoom, F. 2009. Microfinance and Rural Household Development: A 
Ghanaian perspective. Journal of Developing Societies, 25, 85-105

Loca, S. and Kola, F. 2013. Microfinance and Enterprises - Case of Albania. European Scientific Journal. 9(22), $122-143$

Littlefield, E. 2005. Microfinance - Where We Are Now and Where We Are Headed, Microfinance speech given at the International Year of Microcredit and Georgetown University Conference on, Washington DC.

Mayoux, L 2005. Micro-finance and the Empowerment of Women: A Review of Key Issue, Social Finance Unit. IFAD publication.

Mayoux,L.1997. Micro-finance programmes and women's empowerment: towards a framework for participatory planning. United Kingdom: Action Aid.

MoFEP 2012. The Composite Budget of The Tamale Metropolitan Assembly For The 2014 Fiscal Year. [Online] Available: www.mofep.gov.gh (September 9, 2014)

Montogometry, R. 1996. Disciplining or Protecting the Poor? Avoiding the social costs of Peer Pressure in Micro-Credit Schemes. Journal of International Development, 8, 289-305

Mosley, P. and Hulme, D. 1998. Microenterprise Finance: Is there a tradeoff between growth and poverty alleviation, PRUS working paper, No 3

Muktar, M 2009. The role of microfinance banks in the promotion and development of entrepreneurship in semi urban and rural areas. Department of Economics, Bayero University Kano.P.M.B 3011, Kano-Nigeria

Munyao, M. J. 2012. The contribution of microfinance institutions on growth of medium and small scale businesses in Machakos Municipality, Kenya

Navajas, S. Conning J., Gonzalez-Vega C. 2000. Microcredit and poorest of the poor: Theory and Evidence from Bolivia. World Development, 28(2), 333-346

Oti-Boateng, P. and Dawoe, E. 2005. Transformation of microfinance Schemes from Subsistence living to Small-scale enterprises: Analysis of policies that affect the technological capabilities of small and medium scale enterprises in Ghana. Paris: UNESCO

Pronyk, P., Hargreaves, J., and Murdoch, J. 2007. Microfinance Programmes and Better Health: Prospects for Sub Saharan Africa. Journal of American Medical Association, 29(16), 1925-1927

Quaye,D.N.O. 2011. The effect of micro finance institutions on the growth of small and medium scale enterprises (SMEs); a case study of selected SMEs in the Kumasi metropolis. A master's thesis submitted to the Institute of Distance Learning, Kwame Nkrumah University of Science and Technology

Robinson, M. 2004. The Microfinance Revolution: Sustainable Finance for the Poor. Washington D.C.: World Bank. [Online] Available: http://www-wds.worldbank.org/external/default/WDSContentServer/WDSP/IB/2007/08/23/0 
00310607_20070823152333/Rendered/PDF/232500v10REPLA18082134524501PUBLIC1.p df (August 10, 2014)

Roodman, D. 2009. What do we Really Know about Microfinance? [Online] Available: http://blogs.cgdev.org (September 18, 2014)

Sachs, J. 2009. Is Microfinance the Solution to Poverty? [Online] Available: http://www.kiva.org (August 8, 2014)

Shane, S. 2003. A general theory of entrepreneurship: The individual-opportunity nexus. Edward Elgar. UK

Stewart, M \& Hodgjinson, P.E. 1991. Coping with Catastrophe. A handbook of Disaster Management. London, Routledge. [Online] Available: https://books.google.com.gh/books (September 20, 2014)

Thente, S. 2003. Is Micro-credit Enough? A Field Study about Women's Empowerment in Bangladesh. Unpublished Maters Thesis, Department of Political Science, Lund University.

United Nations Capital Development fund (UNCDF), 2009. Enabling Poor Rural People to Overcome Poverty in Ghana. United Nations, New York.

World Bank, 1994. Findings-Africa Region, No. 26. Washington DC.

World Bank, 2002. World Development Report Washington D.C., USA. [Online] Available: http://hdl.handle.net/10986/5984 (July 5, 2014)

Zeller, M. and Sharma, M. 1998. Rural Finance and Poverty alleviation. Washington, DC. USA: International Food Policy Research Institute (IFPRI)

\section{Copyright Disclaimer}

Copyright for this article is retained by the author(s), with first publication rights granted to the journal.

This is an open-access article distributed under the terms and conditions of the Creative Commons Attribution license (http://creativecommons.org/licenses/by/3.0/). 